\title{
Camel Farming Sustainability: The Challenges of the Camel Farming System in the $\mathrm{XXI}^{\text {th }}$ Century
}

\author{
Bernard Faye $e^{1,2}$ \\ ${ }^{1}$ Camel project UTF/SAU/044/SAU, Al-Kharj Agriculture project, Saudi Arabia \\ ${ }^{2}$ UMR SELMET, Centre de Coopération Internationale en recherche agronomique pour le développement \\ (CIRAD-ES). Montpellier, France \\ Correspondence: Bernard Faye, Center for Agriculture Project. P.O. Box n761 Al-Kharj 11942, Saudi Arabia. \\ Tel: 966-538-925-629. E-mail: faye@cirad.fr
}

Received: February 1, 2013 Accepted: March 23, 2013 Online Published: November 25, 2013

doi:10.5539/jsd.v6n12p74 URL: http://dx.doi.org/10.5539/jsd.v6n12p74

\begin{abstract}
In some countries, camel farming is changing from traditional extensive forms to modern semi-intensive or even intensive forms. This could lead to decrease the established perception of the camel farming as an environmentally sustainable production system. The challenges for all camel stakeholders to maintain this image and to promote a "sustainable development" involve the control of the camel demography which must be balanced with the environmental carrying capacity, the preservation of the camel diversity, the development of alternative feeding systems for preserving the water resources in desert areas, the promotion of high-value products to the growing market, the control of the health constraints for a highly mobile camel population, and the respect of the social role of camel in the new living standard.
\end{abstract}

Keywords: camel, sustainable development, farming system, biodiversity, demography, market, water resources

\section{Introduction}

The word sustainability was defined by the United Nations as the development that meets the needs of the present without compromising the ability of future generations to meet their own needs (Adams, 2006). The three pillars of sustainability are regarded as the reconciliation of environmental, social equity and economic demands. However, for some environmentalists, the idea of sustainable development is an oxymoron as development seems to entail environmental degradation (Redclift, 2005). Anyway, even if the concept of sustainability could be regarded as a feel-good buzzword with little meaning or substance, it implies responsible and proactive decision-making and innovation that minimizes negative impact and maintains balance between social, environmental, and economic growth to ensure a desirable planet for all species now and in the future. In that context, the camel, the most important animal domesticated by the mankind in the desert ecosystem, is faced to important challenges because it is directly confronted to one of the hot-spot regarding the interaction livestock/environment (Steinfeld et al., 1999), i.e. the desertification process. It is currently admitted that the camel, being well adapted to such arid environment, it is an environmentally friendship animal and the camel farming system, a low environmental pressure activity (Raziq et al., 2008). Yet, the current changes in the camel farming systems are modifying the traditional relationships between the camel and their environment (Faye et al., 2012). Such evolutions have to be taken in consideration to identify the challenges for a future development of the camel farming worldwide. In the present paper, five aspects regarding the camel sustainability are taken in account: (i) the changes in camel demography reflecting the pressure on the environment, (ii) the preservation of the camel diversity, (iii) the water and the feeding management of camel in new intensive systems, (iv) the integration of camel rearing in global economy, (v) the social dimension of the camel in the desert societies.

\section{Camel Demography, a Contrasted Report}

The ecological footprint is one of the measures to assess the human pressure on the environment. For livestock, the ecological footprint could be appreciated by its environmental carrying capacity, i.e. the ratio between the whole population and the available resources (water, feeding, land) for maintaining the livestock production (Alemayehu et al., 2012). Regarding the camel demography, the number of heads increased regularly since 1961 $(12,926,000)$, but the present estimated world population by FAO $(26,635,000$ in 2011$)$ was under the sum of 
national estimations of domesticated camels for the same year $(28,583,000)$ and not included feral Australian population (1 to 1.5 million heads- Ward and Burrows, 2010). In 2011, the camel population was still mainly concentrated in the Horn of Africa and in Sahelian countries (Figure 1). The camel population in 2011 was slightly more than double than in 1961 (it was multiplied by 2.06), corresponding to annual growth of $2.08 \%$. By comparing this annual growth for the same time interval to other species at world level, the camel population was growing faster than cattle (1.01), sheep (0.20), horse (-0.12) and lama (1.15) and was close to the buffalo population growth (2.38), but lower than the goat population growth $(3.24 \%)$.

However, the annual growth is quite variable from one country to another (from $-2.1 \%$ in former soviet republics to $13 \%$ in Somalia). Overall, the pattern of the annual growth since 50 years allows identifying 5 types of countries described as follow: (i) the countries with a regularly camel population growing mainly based in the Horn of Africa and Near-East; (ii) the countries with a recent but important growth of their camel population, mainly in Western Africa and the Arab Peninsula; (iii) the countries with a stable population (Kuwait, Lebanon, Libya and Senegal ); (iv) the countries with regularly declining camel population (mainly in Central Asia, China and India); (v) the countries with a severe decline (Iraq, Turkey, northern part of Morocco).

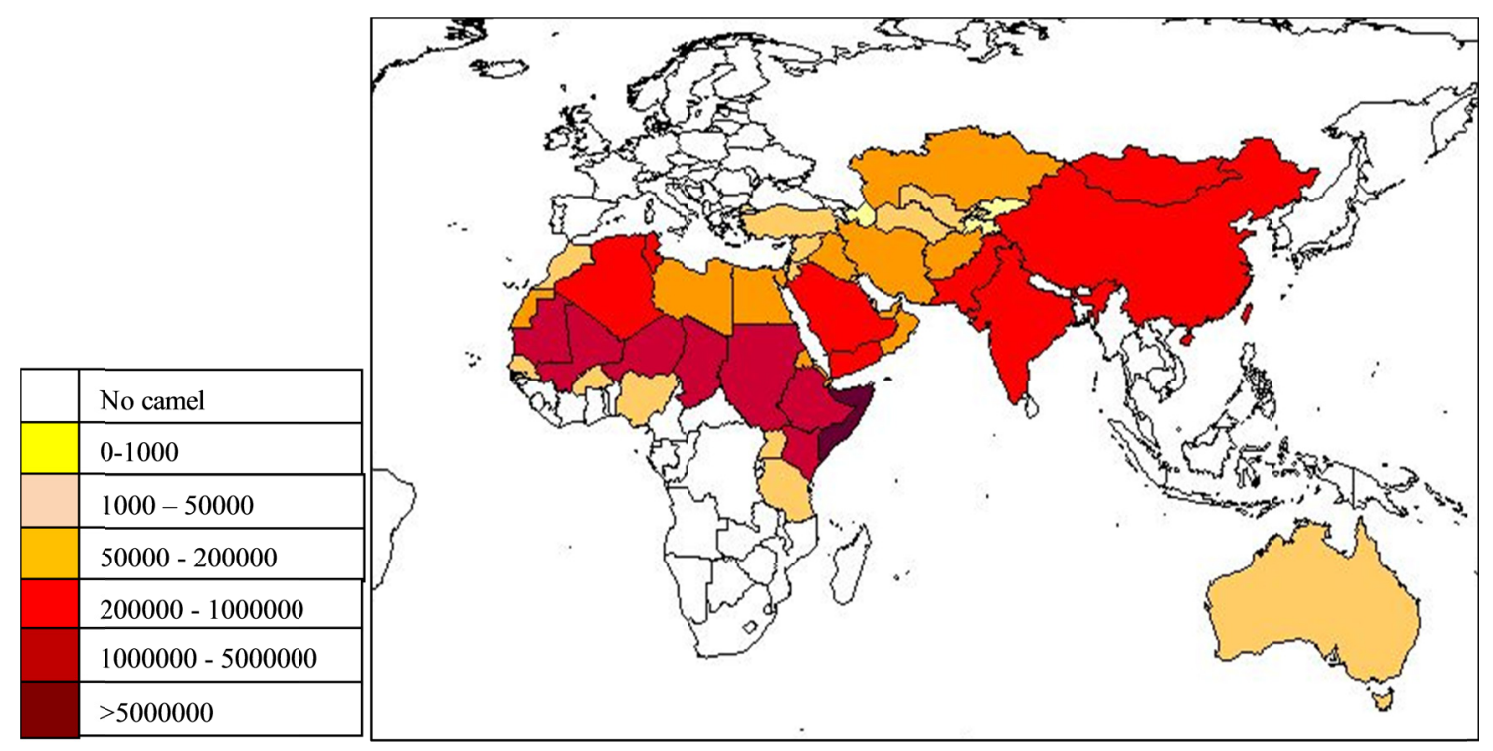

Figure 1. Distribution of the camel population in the world in 2011 (source: Faye \& Bonnet, 2012)

The decline of the camel population is not correlated to the development level of the country. Indeed, there is no correlation between the camel population growth and the gross domestic product per inhabitant, GDP/hab. (Figure 2).

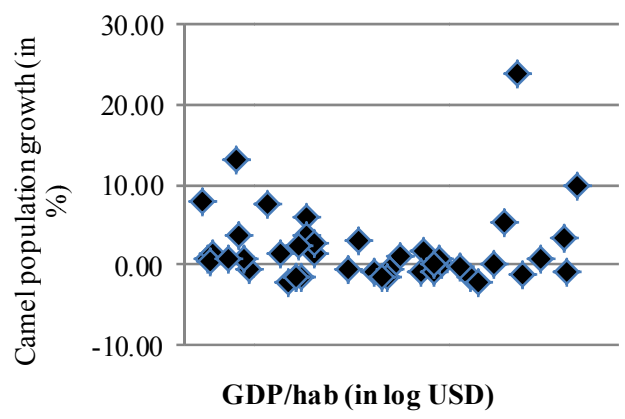

Figure 2. Relationships between camel population growth in "camel countries" and GDP/hab in 2011 (source FAOstat and Wikipedia: http://fr.wikipedia.org/wiki/Liste_des_pays_par_PIB_(PPA)_par_habitant) 
The most important aspect regarding camel demography is not only the growth of the number of heads, but also, the relative importance of camels in the total livestock of the "camel countries". This ratio could be estimated by the percentage of Tropical Livestock Units (TLU) (Note 1) due to camel reported to the total TLU of each country. According to this indicator, five levels of economic importance of camel population could be identified: (i) the countries with marginal importance, the camel population representing less than $2 \%$ of the total TLU (South Asia and Near-East mainly), (ii) the countries with low economic importance (2-5\% of the total TLU; among them Egypt, Libya, Central Asia, Pakistan, Iraq may be mentioned), (iii) the countries with medium importance (5-10\% of the total TLU) as Algeria, Kenya and Ethiopia, (iv) the countries where camel are quite important (10-25\% of the total TLU), mainly belonging to Sahelian countries and the Arabian Peninsula, (v) the countries where camels represented more than $25 \%$ of the whole TLU (Mauritania and Somalia). We could mention also the countries where camel farming is developing as new and marginal livestock activity for different purposes: tourism (Canary Islands in Spain), dairy production (Netherland, USA), diversification in agricultural activities (France) or new implementation in desert area (Namibia).

Another indicator attesting the relative importance of the camel population is the camel density (number of camels per $\mathrm{km}^{2}$ ). The highest densities are observed in the Horn of Africa and the United Arab Emirates (more than 2 camels $\left./ \mathrm{km}^{2}\right)$ and in Sahelian countries $\left(1 \mathrm{camel} / \mathrm{km}^{2}\right)$. The density is lower in Asia except in Pakistan and Afghanistan. These two indicators (percentage of TLU and density) show that the economic importance of camel is quite predominant in Sub-Saharan countries and in the Arabia Peninsula. Thus, the problem of the ecological footprint of the camel stock could appear more acute in those regions of the world. However, it is the balance between the growth in camel population and the ability to maintain a sustainable resource use which must be reached. In that sense, camel productivity must be assessed as it is underlined in the next chapter.

\section{The Camel Diversity, Richness to Preserve}

Based on the official definition of the term biodiversity, we can regard camel diversity as the variability including the totality of genes, breeds and ecotypes of camel worldwide (Benton, 2001). In camel, the selection pressure by human was quite soft compared to other domestic ruminants as cattle, sheep and goat. Contrary, for example, to dairy cattle and goat where the Holstein-Friesian and the Saanen breed became respectively predominant, there was no "invading" camel breed at the world level, and the gene exchanges between camels remain marginal. The selection achieved by the breeders in the camel history had only oriented camel phenotypes for special use as packing, racing and more recently to dairy, meat or wool production. Recent molecular genetic studies regarding camel at world level showed that the camel genetic variability is originating from Arabian Peninsula where the camel diversity is the most important (Almathen et al., 2012) and confirmed the origin of all the dromedary camels in Africa and Asia. For example, a high genetic difference was observed between North and West African types in one hand, and "breeds" from the Horn of Africa in another hand. Thus, these two camel populations are closed to two different camel genotypes from Arabian Peninsula. In Saudi Arabia, 3 main populations were identified, confirmed by phenotypic description (Abdallah \& Faye, 2012).

However, the knowledge regarding the camel breed's or type's performances is still low. Regular records of dairy or growth performances in order to create a nucleus for genetic improvement, is quite marginal and generally involves few animals. Clearly, except some activity on racing camel, there was no national selection program in most of the "camel countries". As the consequence, the camel productivity has not increased sufficiently yet. For example in Saudi Arabia, during the period 1961-2010, milk and meat productivity increased in similar proportion than the camel population (5.2\% per year), i.e. $5.4 \%$ per year for milk production and $6.4 \%$ per year for meat production. The increase of milk and meat productivity was mainly linked to the population growth. Regarding the higher meat production growth, it was rather due to an increase in the slaughtering rate than to improvement in the meat productivity. Indeed, the mean carcass weight resulted to be the same in 2011 compared to $1961(224 \mathrm{~kg}$ ) while the slaughtering rate increased by $6.6 \%$ per year. The dairy productivity also did not change since the last 50 years and the increase in dairy production resulted to be linked to the increase in the proportion of dairy animals passing from 62 to $69 \%$, i.e. an annual growth of $5.5 \%$ (Faye and Bonnet, 2012). In most of the cases, the genetic progress is close to zero because the replacement's camels were selected not on the basis of their additive genetic values for growth traits or dairy production, but mainly on their appearance and conformation (Al-Mutairi et al., 2010).

There is an urgent need for setting up record systems of camel performances of the different breeds and types, for establishing proper selection program for the improvement of the productivity. But, it is necessary also to characterize properly the camel diversity and to preserve some ecotypes having low herd size or living in specific environment. For example, in Saudi Arabia, camel breed as Adhana limited to mountains area (Faye et al., 2011) or in Pakistan, Raigi breed which have relatively low number of heads but are very well adapted to 
specific milieu (Raziq et al., 2011). Some breeds or types could have specific physiology which must be deepen for a better understanding of the adaptation process. For example in Niger, it has been stated that the reproductive performances and reproduction cycle was quite different between Manga and Azarghaf testifying an important physiological difference in the ovarian activity (Vias et al., 2006).

\section{Water and Feeding Management}

It is widely reported that camel is well adapted to ecosystems with low nutritive resources and water scarcity. In that sense, camel is regarded as an environmental friendly animal. Indeed, it presents some advantages compared to ruminants:

- By its ability to stay several days without drinking, it can use rangelands far away from the water points, and then decrease the grazing pressure around them.

- By its feeding behavior, the camel is able to graze a highest variety of plants than the ruminants leading to a lower pressure on the floristic biodiversity of the arid lands (Rutagwenda et al., 1990)

- By its salt tolerance, the camel is able to eat halophyte plants which are unpalatable for the other herbivorous (Yagil, 1985).

- By its special anatomy (long neck), the camel is able to graze the different strata in the pasture ecosystems, from grass to trees with a limited overgrazing (Faye \& Tisserand, 1989).

- By its ambulatory and low gregarious behavior in pasture, the carrying capacity of a camel herd is well distributed in the whole grazing area (Richard, 1985).

- Due to its soft feet devoid of hoof, the walking of a camel herd is less aggressive for the soil than herbivorous with hooves

- Thanks to the longer transit of feed in the digestive tract of camel, the seeds rejected in the feces could increase their germinating power in arid lands better than for ruminants (Trabelsi et al., 2012).

- By its digestive physiology (nitrogen recycling, slow transit, ruminal flora, ...), the camel can better valorize the poor nutritive feedstuffs and shows a better feeding efficiency than cow, contributing to a better resources/production ratio (Jouany, 2000).

However, the current changes in camel farming systems based on intensification of the management could modify this conception. In Saudi Arabia for example (Abdallah \& Faye, 2013), the camel farming systems is moving from the extensive form (the Bedouin system based on camel mobility, low inputs, pastoral feeding and low market integration) to a semi-intensive or even an intensive system (based on feeding by irrigated feedstuffs, settlement and market integration). In such change, the water consumption increased from $3,000 \mathrm{~m}^{3} / \mathrm{ha}$ to 35,000 $\mathrm{m}^{3} /$ ha (Table 1 ). The biomass productivity passing from 5 tons to 18 tons of dry matter per hectare, the water consumption for feeding one camel is multiplied by 3.2 contributing to higher pressure on water resource. The assessment of water consumption per liter of produced milk is multiplied by 9 passing from 938 to 86011 per liter of produced milk (Table 1).

At the national level, based on FAO statistics regarding camel population and considering the percentage of the different systems today (Abdallah \& Faye, 2013) compared to the situation in 1961 where almost all camels were reared in the Bedouin system, the water consumption in Saudi Arabia has increased approximately from $180,000 \mathrm{~m}^{3}$ to $280,000 \mathrm{~m}^{3}$ in the Bedouin system while it passed from 7,000 to $860,000 \mathrm{~m}^{3}$ in intensive system during the last 50 years.

Thus, the water demand increased considerably due to the changes in the farm management regarding especially the feeding systems. This aspect has to be taken into serious account in the near future. The intensification of the camel production is contributing to significantly increase the pressure on the water resources in spite of the ecological advantages of the camel. However, similar estimations have to be done for dairy cattle in similar ecosystem, in order to evaluate the potential comparative advantage of camel for sustainable production. 
Table 1. Assessment of the water consumption in camel farming systems in Saudi-Arabia

\begin{tabular}{lll}
\hline item & Intensive system & Bedouin system \\
\hline water/ha (m3)* & 35000 & 3000 \\
DM production (kg) & 18000 & 5000 \\
$\%$ prot & 14 & 11 \\
Nb camel/ha** & 4.11 & 1.14 \\
water/camel ( l) & 8517 & 2628 \\
prot/animal/ha (g) & 613 & 482 \\
milk/ha (l) & 11.1 & 8.8 \\
water/milk (1/kg) & 8601 & 938 \\
\hline
\end{tabular}

*This number included only the water irrigation for fodders.

** Number of camels theoretically allowed by the total proteins produced per hectare.

In intensive camel production, the technical model adopted by the farmers for the feeding system is mainly based on irrigated alfalfa plus concentrates like barley and/or wheat bran. The use of agro-food by-products is not often suggested. For example, olive cake which is commonly used in desert sheep diet from countries producing olive was rarely tested in camel (Faye et al., 2013). Yet, such by-products could be a partial alternative to the distribution of green forages or cereals obtained by irrigation in a context of very high water constraint contributing to a more sustainable feeding system. It is obvious that alternative ingredients for feeding high-yield camel is a convenient approach for contributing to a better balance between natural resources and camel production. The development of fodder production under salty water irrigation is one of the ways suggested by scientists (Breulmann et al., 2007).

\section{The Integration of Camel Rearing in Global Sustainable Economy}

Mainly used in the past as a "desert ship" for the transportation of goods and human, the camel produced also milk, meat and wool which were self-consumed in most of the cases. In consequence, camel rearing was poorly integrated to market. The growing urbanization and the increase of camel products demand from consumers less connected to Bedouin life have precipitated the market development for the camel products, especially milk which was formerly regarded as a gift for the visitors. However, the challenge for a sustainable economy is to manage economic development without increasing resource use and environmental impact. This must be done by using strategies and technology that break the link between economic growth and environmental damage. In that sense, camel economy has to minimize the depletion of natural capital. In other word, the increasing integration of camel rearing into the market has to take in account the consequences of this development on the environment and social organization of the camel production system. Of course, the intensification process described in the former chapter, subject to the possibilities of offering low "ecological cost" fodder to selected high-yield camels is clearly a way for increasing the camel productivity, but this intensification has to be linked to the production of high quality products (both in term of organoleptic and hygienic aspects) presenting comfortable added values to the producers.

The camel has obviously good assets regarding the quality of its products. Camel milk and camel milk products like fermented milk are acknowledged for their dietetic and even medicinal properties (Konuspayeva et al., 2004). The fermented milk as shubat (Kazakhstan), gariss (Sudan) or zrig (Mauritania) are appreciated for their probiotic virtues. Camel meat is also characterized by high quality protein with low cholesterol content to the consumers (Kadim et al., 2008). Moreover, considerable efforts have been done to propose new milk and meat products (Farah \& Fisher, 2004). Due to the supposed or proved properties of the camel products, their prices on the market are generally high. The camel productions appear rather profitable, although the hygienic conditions could be improved in many cases (Eberlein, 2007).

In several countries, camel dairy plants were implemented contributing to the emerging of powerful value chains leading to a rational organization of camel milk producers, the integration of the camel sector in the national livestock economy, and the development of a distributors' network (Abeiderrahmane, 1997). In Central Asia and in Middle-East, fermented and pasteurized camel milk, as well as camel meat, is available in supermarket. 
Contrary to milk, the camel meat market is regional and lead to important flow of live camel stock, especially from the Sub-Saharan countries and Horn of Africa to northern Africa and Arabian Peninsula (Aklilu \& Catley, 2011). So the pattern for camel meat economy appears different than for milk which remains integrated into local market. The camel meat represents $0.13 \%$ of the total meat consumed in the world and $0.45 \%$ of the herbivorous meat only. However the growth of camel meat production is higher than for cattle meat but comparable to that of buffalo meat. The camel meat production was multiplied by 2.90 between 1961 and 2011 corresponding to an annual growth of $3.5 \%$ that is higher than the camel population growth. The sustainability of such market is depending on two main aspects: the security and the health constraints. The camel stock market for export is widely "informal" (no official declaration) and if the commodity channel is well organized (based on oral agreements and tribal relationships between the stakeholders of the commodity channel), the economic importance of this market at national level is not well documented (Alary \& Faye, 2009). This lack of official implementation contributes to the insecurity all along the trade routes, especially in countries where local conflicts occur (especially in the Horn of Africa). Regarding health aspect, diseases are of particular concern when camels are forced to live outside of their natural habitat. In many countries, the veterinary services are poorly trained for camel health care and accustomed to camel diseases prevention. Mange, plant poisoning or tick infestations are common. Emerging diseases provoking high mortality are also regularly described (Faye et al., 2012; Khalafalla et al., 2010; Roger et al., 2000). Because of the increase in the risk of trans-boundary diseases in camel, the World Animal Health Organization (OIE) in Paris has implemented one ad-hoc group of experts on camel diseases for establishing rules and standards (nomenclature of diseases, diagnosis kits, references lab, etc).

One important point regarding the sustainable camel economy is to integrate (i) ecosystem services offered by the camel farming systems, in one hand, and (ii) negative "externalities" of the camel farming activities on the environment, in another hand. In order to promote "sustainable business practices", the price of the products and the taxes on the trade should include those aspects.

\section{The Social Dimension of the Camel in the Desert Societies}

The social role of camel in the Bedouin way of life and beyond in all the pastoralists' societies from Africa, Central Asia and Middle-East is widely underlined by the anthropologists (see for example Young, 1996). As for other livestock in low input systems, camel is an element of the social prestige of the owners, a capital for ensuring the well-being of their family, and, due to its remarkable resistance to drought, a security face to the climatic changes as it was observed in Sahelian countries (Faye et al., 2012). Its role in the securization of the pastoralists systems is making happen by the switch from cattle to camel in farming systems confronted to repeeted drought, even among traditional cattle breeders like Wodaâbe in Niger, Massaï in Kenya (Potkanski, 1999) or Borana in Ethiopia (Yosef et al., 2013). Because of its longevity and its low reproductive performances compared to small ruminants rather regarded as "coin purse", the camel is really the long-term capital for the mobile family. From this point of view, it contributes strongly to the poverty alleviation by (i) the food security (it can provide milk and meat for self-consumption), (ii) the securization of the long-term capital, (iii) the contribution to the diversification of the incomes in livestock systems including a multi-activity of the family, (iv) the ability to be included into market economy at local or regional level, (v) the contribution to solidarity network among the pastoralists (Faye, 2009).

Moreover, the "traditional life" in the desert is regarded as a "harmonious, symbiotic relationship with the environment" (Breulmann et al., 2007), the pastoralists managing their fragile rangelands without over-exploiting them (Olsvig-Whittaker et al., 2006). This proximity to the nature including the emotional links with the camels could be maintained in spite of the changes in the farming systems described above. In spite of the new standard of life developed in Middle-East, the search for the quality of life, by passing for example the week-end under the Bedouin tent surrounded by the camel herd, is still expected by the recently urbanized people. The challenge of the new camel farming systems based on the intensification of the management and production would be to maintain this relationship.

\section{Conclusion}

The challenges of the livestock farming for a sustainable development are not necessary specific to camel. But, as camel is specifically, "the animal of the desert", there is a special responsibility for the camel stakeholders, producers, decision-makers, or scientists. Face to the camel demography growth at the world level, a better balance with the carrying capacity has to be reached by the intensification of the camel management while respecting camel diversity and water resources. New camel farming systems have to propose products with high 
added values, both in term of quality and of economic interest for a market more and more sensitive to the ecological conditions of production.

\section{References}

Abdallah, H. R., \& Faye, B. (2012). Phenotypic classification of Saudi Arabian camel (Camelus dromedarius) by their body measurements. Emirates Journal of Food and Agriculture, 24(3), 272-280.

Abdallah, H. R., \& Faye, B. (2013). Typology of camel farming system in Saudi Arabia. Emirates Journal of Food and Agriculture, 25(4), 250-260.

Abeiderrahmane, N. (1997). Camel milk and modern industry. Journal of Camel Practice and Research, 4, 223-228.

Adams, W. M. (2006). Report of the IUCN Renowned Thinkers Meeting, 29-31.

Aklilu, Y., \& Catley, A. (2011). Shifting sands: the commercialization of camels in mid-altitude Ethiopia and beyond. Feinstein International Center Publ., Tufts Univ., Medford, USA.

Alary, V. \& Faye, B., (2009). Overview of the camel chains in East of Africa- Importance of gaps between the data and the apparent reality. Proc. of the $2^{\text {nd }}$ conference of ISOCARD, Djerba (Tunisia), 12-14 march 2009, abstr. 92.

Alemayehu, M., Amede, T., Böhme, M., \& Peters K. J. (2012). Increasing livestock water productivity under rain fed mixed crop/livestock farming scenarios of sub-saharan Africa: a review. Journal of sustainable development, 5(7), 1-10. http://dx.doi.org/10.5539/jsd.v5n7p1

Almathen, F., Mwacharo, J., \& Hanotte, O. (2012). Genetic Diversity and Relationships of Indigenous Saudi Arabia Camel Camelus dromedarius Populations Proc. $3^{\text {rd }}$ ISOCARD Int. Conf., (Ed. I. Kadim), 29/01 to 01/02/12, Muscat, Oman, 40-42

Almutairi, S. E., Boujenane, I., Musaad, A., \& Awad-Acharari, F. (2010). Genetic and non-genetic effects for milk yield and growth traits in Saudi camel. Tropical Animal Health Production, 42, 1845-1853. http://dx.doi.org/10.1007/s11250-010-9647-6

Benton, M. J. (2001). Biodiversity on land and in the sea. Geological Journal, 36(3-4), 211-230. http://dx.doi.org/10.1002/gj.877

Breulmann, M., Boer, B., Wernery, U., Wernery, R., El-Shaer, H., Alhadrami, G., ... Norton, J., (2007). The camel, from tradition to modern times. Unesco Doha Publ., Doha (Qatar).

Eberlein, V. (2007). Hygienic status of camel milk in Dubai (United Arab Emirates) under two different milking management systems. Dissertation, LMU München: Faculty of Veterinary Medicine, München, Germany, $1-101$.

Farah, Z., \& Fisher, A. (2004). Milk and meat from the camel. Handbook on products and processing. Swiss Federal Institute of Technology, Verlag Publ., Zurich, Switzerland.

Faye, B. (2009). Pauvreté et solidarité chez les peuples pastoraux. Chap. 8. In L'élevage, richesse des pauvres, Coll. Update, Duteurtre G et Faye B. (coord.) QUAE publ., Versailles, 77-87.

Faye, B., Abdallah, H., Almathen, F., Harzallah, B., \& Al-Mutairi, S. (2011). Camel biodiversity. Camel phenotypes in the Kingdom of Saudi Arabia. Camel Breeding, Protection and Improvement Center, project UTF/SAU/021/SAU, FAO publ., Riyadh (Saudi Arabia).

Faye B., Chaibou, M., \& Vias, G. (2012). Integrated impact of climate change and socioeconomic development on the evolution of camel farming systems. British Journal of Environment and Climatic Change, 2(3), 227-244. http://dx.doi.org/10.9734/BJECC/2012/1548

Faye, B., \& Bonnet, P. (2012). Camel sciences and economy in the world: current situation and perspectives. Proc. 3rd ISOCARD conference. Keynote presentations. 29th January -1st February, 2012, Mascate (Sultanate of Oman), 2-15.

Faye, B., Konuspayeva, G., Narmuratova, M., Serikbaeva, A., Musaad, A. M., \& Mehri, H. (2013). Effect of crude olive cake supplementation on camel milk production and fatty acid composition. Dairy Sciences and Technology, 93, 225-239. http://dx.doi.org/10.1007/s13594-013-0117-6

Faye, B., \& Tisserand, J. L. (1989). Problèmes de la détermination de la valeur alimentaire des fourrages prélevés par le dromadaire. Séminaire sur la nutrition et l'alimentation du dromadaire, Ouargla, Algérie. Options méditerranéennes. Séries séminaires, n2, 61-65. 
Jouany J. P. (2000). La digestion chez les camélidés: comparaison avec les ruminants. INRA Productions Animales, 13(3), 165-176.

Kadim, I. T., Mahgoub, O., \& Purchas, R. W. (2008). A review of the growth, and of the carcass and meat quality characteristics of the one-humped camel (Camelus dromedaries). Meat Science, 80, 555-569. http://dx.doi.org/10.1016/j.meatsci.2008.02.010

Khalafalla, A. I., Saedd, I. K., Ali, Y. H., Abdurrahman, M. B., Kwiatek, O., Libeau, G., ... Abbas, Z. (2010). An outbreak of peste des petits ruminants (PPR) in camels in the Sudan. Acta tropica, 116, 161-165. http://dx.doi.org/10.1016/j.actatropica.2010.08.002

Konuspayeva, G., Loiseau, G., \& Faye, B. (2004). La plus-value « santé » du lait de chamelle cru et fermenté : l'expérience du Kazakhstan. Rencontres Recherches Ruminants, 11, 47-50.

Olsvig-Whittaker, I., Frankenberg, E., Perevolotsky, A., \& Ungar, E. D. (2006). Grazing, overgrazing and conservation. Changing concepts and practices in the Negev rangelands. Sécheresse, 17, 195-199.

Potkanski, T. (1999). Mutual assistance among the Ngorongoro Maasai. In : « The poor are not us. Poverty and pastoralism », D. M. Anderson and V. Broch-Due (Eds.), Publ. Eastern African Studies, Oxford, 199-217.

Raziq, A., Tareen, A. M., \& De Verdier, K. (2011). Characterization and significance of Raigi camel, a livestock breed of the Pashtoon pastoral people in Afghanistan and Pakistan. Journal of Livestock Sciences, 2, 11-19.

Raziq, A., Younas, M., \& Kakar, M. A. (2008). Camel A potential dairy animal in difficult environments. Pakistan Journal of Agricultural Sciences, 45(2), 263-267.

Redclift, M., (2005). Sustainable development (1987-2005): an oxymoron comes of age. Sustainable Development, 13(4), 212-227. http://dx.doi.org/10.1002/sd.281

Richard, D. (1985). Le dromadaire et son élevage. Publ. IEMVT, Coll 3etudes et synthèses", CIRAD-Montpellier, France, 162 p.

Roger, F., Diallo, A., Yigezu, L. M., Hurard, C., Libeau, G., Mebratu, G. Y., \& Faye, B. (2000). Investigations of a new pathological condition of camels in Ethiopia. Journal of Camel Practice and Research, 7(2), 163-166.

Rutagwenda, T., Lechner-Doll, M., Schwartz, H. J., Schultka, W., \& Von Engelhardt, W. (1990). Dietary preference and degrability of forage on a semi-arid thornbush savannah indigenous ruminants, camels and

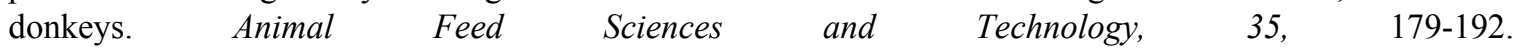
http://dx.doi.org/10.1016/0377-8401(90)90123-P

Steinfeld, H., De Haan, C., \& Blackburn, H. (1999). Interactions entre l'élevage et l'environnement. Problématique et propositions (p. 52). CIRAD, Montpellier, France.

Trabelsi, H., Chehma, A., Senoussi, A., \& Faye, B. (2012). The Contribution of the dromedary in the spontaneous plant seeds transfer in the Northern Algerian Sahara. Journal of Life Sciences, 6(3), 300-303.

Vias, G., Faye, B., Kane, Y., Diarra, A., Laouali, G., \& Daouda, H. (2006). Performances de reproduction de la femelle dromadaire (Camelus dromedarius) dans la zone pastorale de Zinder (Niger). Revue Africaine de Santé et Productions Animales (RASPA), 4, 111-116.

Ward, B., Burrows, N., \& Lethbridge, M. (2010). Inland invaders: a million wild camels. Landscape, 26(1), 40-44.

Yagil, R. (1985). The desert camel. Comparative physiological adaptation. Karger, Basel, Switzerland.

Young, W. (1996). The Rashaayda Bedouin Arab pastoralists of Eastern Sudan. Harcourt Brace College Publishers, UK.

Yosef, T., Mengistu, U., Solomon, A., Mohammed, Y. K., \& Kefelegn, K. (2013). Camel and cattle population dynamics and livelihood diversification as a response to climate change in pastoral areas of Ethiopia. Livestock Research for Rural Development, 25(9). http://www.lrrd.org/lrrd25/9/yosed25166.htm 


\section{Note}

Note 1. Tropical Livestock unit on the basis of cattle $=1 \mathrm{TLU}$, camel=1.2 TLU, horse $=1$ TLU and small ruminants $=0.2$ TLU (dico-sciences-animales.cirad.fr/liste-mots.php?fiche=28301)

\section{Copyrights}

Copyright for this article is retained by the author(s), with first publication rights granted to the journal.

This is an open-access article distributed under the terms and conditions of the Creative Commons Attribution license (http://creativecommons.org/licenses/by/3.0/). 